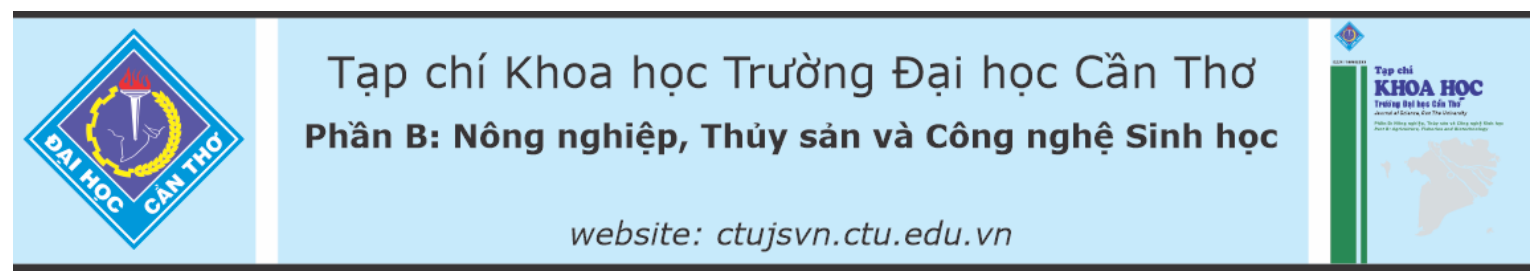

DOI:10.22144/ctu.jvn.2021.181

\title{
KHẢO SÁT CÁC ĐIỀU KIỆN LÊN MEN VÀ HOẠT TÍNH KHÁNG OXY HÓA CỦA RỰU VANG CHÙM RUỘT (Phyllanthus acidus (L.) SKEELS)
}

Huỳnh Ngọc Thanh Tâm ${ }^{1 *}$, Nguyễn Ngọc Phương Trang ${ }^{2}$, Trần Thị Mai Thi ${ }^{2}$, Nguyễn Thanh Thảo Nguyên ${ }^{2}$ và Lâm Thảo $\mathrm{Nhi}^{3}$

${ }^{l}$ Viện Nghiên cưu và Phát triển Công nghệ Sinh học, Truờng Đại học Cần Tho'

${ }^{2}$ Sinh viên ngành Công nghệ Sinh học K43, Truoòng Đại học Cần Tho

${ }^{3} H o c$ viên cao học ngành Công nghệ Sinh học K26, Truờng Đại học Cần Tho

*Người chịu trách nhiệm về bài viết: Huỳnh Ngọc Thanh Tâm (email: hnttam@ctu.edu.vn)

\section{Thông tin chung:}

Ngày nhận bài: 09/08/2021

Ngày nhận bài sủa: 14/10/2021

Ngày duyệt đăng: 25/12/2021

Title:

Determination of fermentation conditions and antioxidant activity of Phyllanthus acidus (L.) SKEELS wine

\section{Tù khóa:}

Chùm ruột, hoạt tính kháng oxy hóa, nấm men, ruợu vang, Saccharomyces cerevisiae

Keywords:

Antioxidant activity, Phyllanthus acidus (L.) SKEELS, Saccharomyces cerevisiae, yeast, wine

\begin{abstract}
This study was to determine the conditions effecting wine fermentation process of Phyllanthus acidus (L.) Skeels using Saccharomyces cerevisiae. Design Expert 7.0 was used to determine optimal factors including $p H$, ${ }^{\circ}$ Brix and yeast cell density. The results indicated that, with $\mathrm{pH} 4.77$, $24.79^{\circ}$ Brix and $8.08 \times 10^{6}$ cells $/ \mathrm{mL}$, after 14 days of fermentation, the highest alcohol content reached $8.88 \% \mathrm{v} / \mathrm{v}$. Simultaneously, 11 compounds have been identified through spectroscopic methods, including steroids, triterpenoids, phenols, tannins, flavonoids, quinones, saponins, antocyanins, glucose, carotenoids and alkaloids from initial juice and wine product. The total polyphenol content of wine was higher than Otaheite gooseberry juice, particularly $297.573 \mathrm{mgGAE} / \mathrm{L}$ and $174.549 \mathrm{mgGAE} / \mathrm{L}$ respectively. After fermentation, the reduction DPPH capacity of wine reached an $I_{50}$ value at $45.132 \mu \mathrm{L} / \mathrm{mL}$, which is higher than otaheite gooseberry juice (IC 50 value at $59.973 \mu \mathrm{L} / \mathrm{mL}$.), shows that wine has better antioxidant activities than the otaheite gooseberry juice.
\end{abstract}

\section{TÓM TĂT}

Nghiên cúu được thưc hiện với muc tiêu xác định các điều kiện ảnh hưởng đến quá trình lên men ruợu vang chùm ruột (Phyllanthus acidus (L.) Skeels) sủ dụng dòng nấm men Saccharomyces cerevisiae. Phần mềm Design Expert 7.0 được sủ dụng để xác định các thông số tối ưu bao gồm $\mathrm{pH}$, độ Brix và MSNM. Kết quả cho thấy với $\mathrm{pH} 4,77,24,79^{\circ}$ Brix và $M S N M$ ban đầu là $8,08 \times 10^{6}$, tế bào/mL sau 14 ngày lên men cho độ cồn cao nhất đạt $8,88 \%$ v/v. Mườ một hợp chất thực vật tù dịch trái và ruợu vang chùm ruột được xác định thông qua phuơng pháp quang phổ bao gồm steroid, triterpenoid, phenol, tannin, flavonoid, quinone, saponin, antocyanin, glucose, carotenoid và alkaloid. Hàm luợng polyphenol tổng của rựu vang chùm ruột cao hơn dịch trái, cu thể là 297,573 mg GAE/L và 174,549 mg GAE/L. Sau quá trình lên men, khả năng khư gốc DPPH của rườu vang chùm ruột có giá trị $I C_{50}$ là $45,132 \mu \mathrm{L} / \mathrm{mL}$, tăng so với dịch chùm ruột ban đầu với giá trị IC 50 là $59,973 \mu \mathrm{L} / \mathrm{mL}$, cho thấy ruợu vang chùm ruột có khả năng kháng oxy hóa tốt hơn dịch trái chùm ruột ban đầu. 


\section{GIỚI THIÊUU}

Chùm ruột (Phyllanthus acidus (L.) Skeels) thuộc họ Phyllanthaceae (Diệp hạ châu), là loài cây nhiệt đới và cận nhiệt đới có nguồn gốc từ Madagascar (đảo quốc ở Ấn Độ Dương) (Morton et al., 1987). Hầu hết các bộ phận của cây bao gồm lá, trái, thân cây đều có những hợp chất quý và góp phần trong việc điều trị bệnh cũng như cải thiện sức khỏe con người (Tan et al., 2020). Trái chùm ruột có vị chua, tính mát có chứa nhiều thành phần dinh dưỡng như chất xơ, kali, sắt, vitamin $\mathrm{C}$ (Monica et al., 2010). Chùm ruột có chứa nhiều hợp chất như terpenoid (diterpenoid, sesquiterpe-noid và triterpenoid), nucleoside, flavonoid và các hợp chất phenolic (Tan et al., 2020). Nhiều nghiên cứu trên thế giới cũng được thực hiện để đánh giá khả năng kháng khuẩn và hoạt tính chống oxy hóa đối với các bộ phận khác nhau của chùm ruột.

Ở Việt Nam, cây chùm ruột trồng phổ biến ở miền Nam, cho trái vào tháng $6-8$ và có thể cho những đợt trái khác trong năm. Tuy nhiên, giá trị kinh tế của trái chùm ruột không cao và các sản phẩm từ trái chùm ruột còn hạn chế nên dẫn đến việc lãng phí nguồn nguyên liệu giàu dinh dưỡng này. Rượu vang là loại rượu đang được ưa chuộng do có độ cồn nhẹ, hương vị thơm tự nhiên, tốt cho sức khỏe như kích thích tiêu hóa... Sử dụng dòng nấm men Saccharomyces cerevisiae là chủng nấm men truyền thống được ứng dụng trong lên men rượu và được sử dụng rộng rãi trong công nghiệp lên men ethanol (Radecka et al., 2015). Bên cạnh đó, lựa chọn các yếu tố như độ $\mathrm{pH}$, độ Brix và mật số nấm men (MSNM) là những yếu tố cơ bản ảnh hưởng nhiều đến quá trình lên men rượu vang. Kết hợp với phương pháp Box-Behnken là công cụ tối ưu hóa có hiệu quả, thể hiện các tác động của từng yếu tố ảnh hưởng và sự tương tác các yếu tố. Vì vậy, nghiên cứu này được thực hiện nhằm tìm ra những điều kiện phù hợp cho quá trình lên men rượu vang chùm ruột cũng như góp phần đa dạng hóa các sản phẩm lên men từ trái cây. Đồng thời, nghiên cứu cũng xác định các hợp chất thực vật cũng như đánh giá các hoạt tính kháng oxy hóa có trong dịch trái chùm ruột trước và sau lên men rượu sẽ tạo tiền đề cho những nghiên cứu tiếp theo nhằm nâng cao giá trị kinh tế và khai thác giá trị y học của loài thực vật này.

\section{VÂT LIÊU VÀ PHƯƠNG PHÁP NGHIÊN CÚU}

\subsection{Vật liệu và hóa chất}

Vật liệu: Trái chùm ruột được thu vào tháng 8/2020 ở Cần Thơ. Mẫu được thu thập và đóng gói trong bao PE (polyetylen) và mẫu được trữ lạnh trong các thùng xốp, tránh ánh sáng mặt trời trực tiếp.

Hóa chất: $\mathrm{NaHSO}_{3}$, ethanol, $\mathrm{NaOH}, \mathrm{H}_{2} \mathrm{SO}_{4}$, $\mathrm{HCl}$, gallic acid, ascorbic acid (vitamin C), $\mathrm{Na}_{2} \mathrm{HPO}_{4} .2 \mathrm{H}_{2} \mathrm{O}, \quad \mathrm{NaH}_{2} \mathrm{PO}_{4} .12 \mathrm{H}_{2} \mathrm{O}$, methanol, $\mathrm{K}_{2} \mathrm{Cr}_{2} \mathrm{O}_{7}$, thuốc thử Folin-Ciocalteu, $\mathrm{Na}_{2} \mathrm{CO}_{3}$ (điều chỉnh $\mathrm{pH}$ ), đường saccharose. Tất cả các hóa chất được sản xuất từ Trung Quốc ngoại trừ ethanol (Việt Nam) và Folin-Ciocalteu (Đức).

Nguồn giống nấm men: Sử dụng dòng nấm men Saccharomyces cerevisiae 2.1 (Hoa Kỳ), được lưu giữ ở Viện Nghiên cứu và Phát triển Công nghệ Sinh học, Trường Đại học Cần Thơ.

\section{2. Ảnh hưởng của độ $\mathrm{Brix}, \mathrm{pH}$ và $\mathrm{MSNM}$ đến quá trình lên men rượu vang chùm ruột}

Mục tiêu của thí nghiệm là xác định ảnh hưởng của độ Brix, $\mathrm{pH}$ và $\mathrm{MSNM}$ đến quá trình lên men rượu vang chùm ruột. Thí nghiệm được bố trí gồm 3 nhân tố theo thể thức Box-Behnken, phần mềm Design Expert 7.0. Nhân tố của thí nghiệm gồm có: Độ Brix (thấp nhất là 20 , cao nhất là 30 ), pH (thấp nhất là 4,5 , cao nhất là 5,5 ) và $\mathrm{MSNM}$ (tế bào $/ \mathrm{mL}$ ) (thấp nhất là $10^{3}$, cao nhất là $10^{7}$ ). Thí nghiệm được bố trí với các thông số được mô tả ở Bảng 1 .

Bảng 1. Bố trí thí nghiệm theo thể thức BoxBehnken của phần mềm Design Expert 7.0

\begin{tabular}{crrr}
\hline $\begin{array}{c}\text { Số nghiệm } \\
\text { thức }\end{array}$ & ${ }^{\mathbf{o}}$ Brix & pH & $\begin{array}{r}\text { MSNM } \\
\text { (tb/mL) }\end{array}$ \\
\hline 1 & 20 & 4,5 & $10^{3}$ \\
2 & 20 & 5,5 & $10^{3}$ \\
3 & 20 & 4,5 & $10^{7}$ \\
4 & 20 & 5,5 & $10^{7}$ \\
5 & 20 & 5 & $5 \times 10^{6}$ \\
6 & 25 & 4,5 & $5 \times 10^{6}$ \\
7 & 25 & 5,5 & $5 \times 10^{6}$ \\
8 & 25 & 5 & $10^{3}$ \\
9 & 25 & 5 & $10^{7}$ \\
10 & 25 & 5 & $5 \times 10^{6}$ \\
11 & 30 & 4,5 & $10^{3}$ \\
12 & 30 & 5,5 & $10^{3}$ \\
13 & 30 & 4,5 & $10^{7}$ \\
14 & 30 & 5,5 & $10^{7}$ \\
15 & 30 & 5 & $5 \times 10^{6}$ \\
\hline
\end{tabular}

Dịch nấm men được chuẩn bị và kiểm tra mật số tế bào nấm men bằng phương pháp đếm trực tiếp bằng buồng đếm hồng cầu để có MSNM theo bố trí thí nghiệm. Trái chùm ruột được ép để lấy nước và 
thanh trùng bằng $\mathrm{NaHSO}_{3}(140 \mathrm{mg} / \mathrm{L})$ trong 2 giờ để tiêu diệt vi sinh vật có trong dịch trái. Các nghiệm thức được điều chỉnh theo các thông số bố trí của độ Brix $(20,25,30)$ bằng khúc xạ kế, $\mathrm{pH}(4,5,5,0,5,5)$ bằng $\mathrm{pH}$ kế. Sau đó, $1 \mathrm{~mL}$ dịch nấm men ở các mật số khác nhau được cho vào $99 \mathrm{~mL}$ mỗi dịch phối chế đã chuẩn bị sẵn trong bình tam giác, lắc đều bình tam giác để tế bào nấm men phân bố đều trong dịch trái chùm ruột. Các bình lên men được gắn waterblock và để ở nhiệt độ phòng. Sau thời gian 14 ngày, việc chưng cất được tiến hành để thu cồn, độ cồn được xác định bằng cồn kế và quy về nồng độ ethanol ở $20^{\circ} \mathrm{C}$ (Nguyễn Đình Thưởng \& Nguyễn Thanh Hằng, 2007). Các chỉ tiêu theo dõi và đánh giá bao gồm $\mathrm{pH}$, độ Brix và nồng độ ethanol.

\subsection{Khảo sát hoạt tính kháng oxy hóa của dịch trái chùm ruột và rượu vang chùm ruột}

\subsection{1. Định tính các hợp chất thực vật}

Mục tiêu là xác định sự hiện diện của các hợp chất thực vật là steroid, triterpenoid, quinone, phenol, tannin, flavonoid, carotenoid, anthocyanin, saponin, alkaloid trong dịch trái chùm ruột ban đầu và sản phẩm rượu vang chùm ruột ở thí nghiệm 2.2. Phương pháp quang phổ UV-VIS được sử dụng theo mô tả của Harbone (1973). Mỗi nghiệm thức sẽ được pha loãng ở nồng độ $10 \mu \mathrm{g} / \mathrm{mL}$ với dung môi methanol và đo độ hấp thụ với tia UV-VIS, sử dụng máy đo quang phổ (Hitachi U-1500) ở dãy bước sóng từ $215 \mathrm{~nm}$ đến $550 \mathrm{~nm}$ với đối chứng là methanol.

\subsubsection{Khảo sát hàm lượg polyphenol tổng}

Mục tiêu là xác định hàm lượng polyphenol tổng có trong dịch trái chùm ruột và rượu vang chùm ruột. Hàm lượng polyphenol tổng được xác định dựa trên phương pháp Folin - Ciolcateau được mô tả bởi Hossain et al. (2013) có hiệu chỉnh bằng cách sử dụng gallic acid làm hợp chất polyphenol chuẩn, dung môi là methanol. Độ hấp thụ của dung dịch màu xanh được ghi nhận bằng máy đo quang phổ (Hitachi U-1500) ở bước sóng $\lambda=765 \mathrm{~nm}$. Hàm lượng polyphenol tổng được xác định theo công thức sau:

$$
P=\frac{a \times V}{m}
$$

Trong đó, $\mathrm{P}$ : hàm lượng polyphenol tổng $(\mathrm{mg}$ gallic $\mathrm{acid} / \mathrm{mL}$ dịch trích), $\mathrm{a}$ : giá trị $\mathrm{x}$ từ đường chuẩn với gallic acid $(\mu \mathrm{g} / \mathrm{mL}), \mathrm{V}$ : thể tích dung dịch dịch quả $(\mathrm{mL}), \mathrm{m}$ : khối lượng có trong thể tích $(\mathrm{g})$.

\subsubsection{Khảo sát khả năng kháng sụ oxy hóa}

Mục tiêu là xác định khả năng khử gốc tự do DPPH (2,2-diphenyl-1-picrylhydrazyl) của dịch trái chùm ruột và rượu vang chùm ruột. Khả năng kháng oxy hóa được xác định dựa trên phương pháp thu nhặt gốc tự do DPPH (2,2-diphenyl-1picrylhydrazyl), được mô tả bởi Mohamed et al. (2013). Giá trị $\mathrm{IC}_{50}$ được sử dụng để so sánh khả năng ức chế gốc $\mathrm{DPPH}$ của dịch trái chùm ruột và rượu vang chùm ruột. $\mathrm{IC}_{50}$ là nồng độ của mẫu mà tại giá trị đó có thể ức chế $50 \%$ gốc tự do DPPH.

Khả năng khử gốc DPPH được xác định theo công thức sau:

$$
I C=\frac{A D P P H-A S}{A D P P H} \times 100
$$

Trong đó, IC: phần trăm ức chế (\%), ADPPH: độ hấp thu ánh sáng của dung dịch DPPH, AS: độ hấp thu của dung dịch khi chiết xuất mẫu được thêm vào.

\subsection{Xử lý số liệu}

Số liệu được thu thập, xử lí và vẽ biểu đồ bằng phần mềm Microsoft Excel 2013(Microsoft). Thí nghiệm được bố trí và xác định các thông số tối ưu theo phần mềm Design Expert 7.0 (Stat-Ease Inc). Số liệu thu thập được xử lý thống kê bằng phần mềm SPSS Statistics 20 (IBM).

\section{KẾT QUẢ VÀ THẢO LUẬN}

\section{1. Ảnh hưởng của độ Brix, $p H$ và MSNM}

Kết quả khảo sát ảnh hưởng của các nhân tố độ Brix, $\mathrm{pH}$ và MSNM đến quá trình lên men rượu vang chùm ruột được thể hiện ở Bảng 2. 
Bảng 2. Giá trị pH, Độ Brix và độ cồn trung bình sau lên men

\begin{tabular}{crrrrrr}
\hline Nghiệm thức & ${ }^{\circ}$ Brix & pH & MSNM & Độ Brix sau lên men & pH sau lên men & Độ cồn (\% v/v) \\
\hline 1 & 20 & 4,5 & $10^{3}$ & $7,83^{\text {ab }}$ & 4,40 & $3,96^{\text {de }}$ \\
2 & 20 & 5,5 & $10^{3}$ & $16,17^{\mathrm{g}}$ & 5,36 & $0,53^{\mathrm{f}}$ \\
3 & 20 & 4,5 & $10^{7}$ & $9,17^{\mathrm{bcd}}$ & 4,45 & $3,97^{\mathrm{de}}$ \\
4 & 20 & 5,5 & $10^{7}$ & $8,83^{\mathrm{abc}}$ & 5,12 & $3,32^{\mathrm{e}}$ \\
5 & 20 & 5,0 & $5 \times 10^{6}$ & $7,67^{\mathrm{a}}$ & 4,59 & $4,96^{\mathrm{bcd}}$ \\
6 & 25 & 4,5 & $5 \times 10^{6}$ & $10,67^{\mathrm{e}}$ & 4,38 & $7,86^{\mathrm{a}}$ \\
7 & 25 & 5,5 & $5 \times 10^{6}$ & $14,83^{\mathrm{g}}$ & 5,33 & $5,40^{\mathrm{bc}}$ \\
8 & 25 & 5,0 & $10^{3}$ & $13,33^{\mathrm{f}}$ & 4,72 & $6,07^{\mathrm{b}}$ \\
9 & 25 & 5,0 & $10^{7}$ & $9,83^{\mathrm{cde}}$ & 4,65 & $8,09^{\mathrm{a}}$ \\
10 & 25 & 5,0 & $5 \times 10^{6}$ & $10,33^{\mathrm{de}}$ & 4,54 & $8,86^{\mathrm{a}}$ \\
11 & 30 & 4,5 & $10^{3}$ & $18,67^{\mathrm{h}}$ & 4,24 & $4,65^{\mathrm{cd}}$ \\
12 & 30 & 5,5 & $10^{3}$ & $27,33^{\mathrm{i}}$ & 5,38 & $0,23^{\mathrm{f}}$ \\
13 & 30 & 4,5 & $10^{7}$ & $19,17^{\mathrm{h}}$ & 4,31 & $5,98^{\mathrm{b}}$ \\
14 & 30 & 5,5 & $10^{7}$ & $19,17^{\mathrm{h}}$ & 5,29 & $4,32^{\text {cde }}$ \\
15 & 30 & 5,0 & $5 \times 10^{6}$ & $18,17^{\mathrm{h}}$ & 4,50 & $5,97^{\mathrm{b}}$ \\
\hline
\end{tabular}

Số liệu là trung bình của 3 lần lặp lại. Trong cùng một cột, các số có mang số mũ giống nhau thì khác biệt không ý nghĩa thống kê ở míc 5\% $(P<0,05)$.

Kết quả cho thấy hai nghiệm thức 9 và 10 cho hàm lượng ethanol trên $8 \% \mathrm{v} / \mathrm{v}$ trong 15 nghiệm thức với độ cồn trung bình ở $20^{\circ} \mathrm{C}$ lần lượt là $8,09 \%$ và $8,86 \% \mathrm{v} / \mathrm{v}$. Các nhân tố độ $\mathrm{Brix}(\mathrm{A}), \mathrm{pH}(\mathrm{B})$ và MSNM $(\mathrm{C})$ đều có ảnh hưởng đến độ cồn trong quá trình lên men rượu vang. Kết quả phân tích thống kê thể hiện ở Bảng 3 cho thấy ảnh hưởng của từng biến độc lập riêng lẻ $(\mathrm{A}, \mathrm{B}, \mathrm{C})$, giá trị bậc hai $\left(\mathrm{A}^{2}, \mathrm{~B}^{2}, \mathrm{C}^{2}\right)$ hay tương tác $(\mathrm{BC})$ đều thể hiện có ý nghĩa $(\mathrm{p}<0,05)$.

Bảng 3. Kết quả phân tích thống kê ANOVA mức độ ý nghĩa của các hệ số hồi quy cho quá trình lên men

\begin{tabular}{crrrrr}
\hline Nguồn & $\begin{array}{r}\text { Tổng bình } \\
\text { phương }\end{array}$ & Độ tụ̂ do & $\begin{array}{r}\text { Bình phương } \\
\text { trung bình }\end{array}$ & Giá trị $\mathbf{F}$ & Giá trị P \\
\hline Mô hình (Model) & 83,41 & 9 & 9,27 & 69,95 & 0,0001 \\
$\mathrm{~A}$ & 1,94 & 1 & 1,94 & 14,62 & 0,0123 \\
$\mathrm{~B}$ & 15,93 & 1 & 15,93 & 119,69 & 0,0001 \\
$\mathrm{C}$ & 10,49 & 1 & 10,49 & 78,80 & 0,0003 \\
$\mathrm{~A}^{2}$ & 16,64 & 1 & 16,64 & 125,06 & 0,0001 \\
$\mathrm{~B}^{2}$ & 4,89 & 1 & 4,89 & 36,74 & 0,0018 \\
$\mathrm{BC}$ & 3,84 & 1 & 3,84 & 28,83 & 0,0030 \\
$\mathrm{C}^{2}$ & 2,22 & 1 & 2,22 & 16,68 & 0,0095 \\
\hline
\end{tabular}

Mô hình tương quan xây dựng từ thí nghiệm đã thỏa điều kiện với thông số $\mathrm{R}^{2}$ cao $\left(\mathrm{R}^{2}=97,27 \%\right)$ và giá trị Adjusted (Adj.) $\mathrm{R}^{2}$ đạt 96,85\%. Trong đó, khoảng 2,7\% tổng số biến không được giải thích bằng mô hình này. Mặt khác, giá trị hệ số xác định tương quan $\mathrm{R}^{2}$ của mô hình còn thể hiện sự tương thích cao giữa các giá trị thực nghiệm và các giá trị dự đoán. Mô hình tương quan được đánh giá tốt khi hệ số xác định tương quan $\mathrm{R}^{2}$ lớn hơn 0,8 (Guan \& Yao, 2008). Như vâyy, mô hình hồi quy đa chiều mô tả mối quan hệ giữa độ cồn sinh ra và các biến độc lập được thiết lập.
Để xác định điều kiện lên men tối ưu từ các thông số $\mathrm{pH},{ }^{\circ}$ Brix và $\mathrm{MSNM}$, độ cồn sau lên men được phân tích bằng chương trình Design Expert 7.0 với độ tin cậy $95 \%$, thu được phương trình hồi quy như sau:

Ethanol $=-206,28668+5,90261 * \mathrm{~A}+$ $59,40293 * \mathrm{~B}-1,09259 \mathrm{E}-006 * \mathrm{C}-0,10183 * \mathrm{~A} * \mathrm{~B}+$ $1,33180 \mathrm{E}-008 * \mathrm{~A} * \mathrm{C}+2,78861 \mathrm{E}-007 * \mathrm{~B} * \mathrm{C}-$ $0,10745 * A^{2}-6,07849 * B^{2}+0,000000 * C^{2}$ (1)

Trong đó $\mathrm{A}, \mathrm{B}, \mathrm{C}$ lần lượt là giá trị độ Brix, $\mathrm{pH}$ và MSNM. 

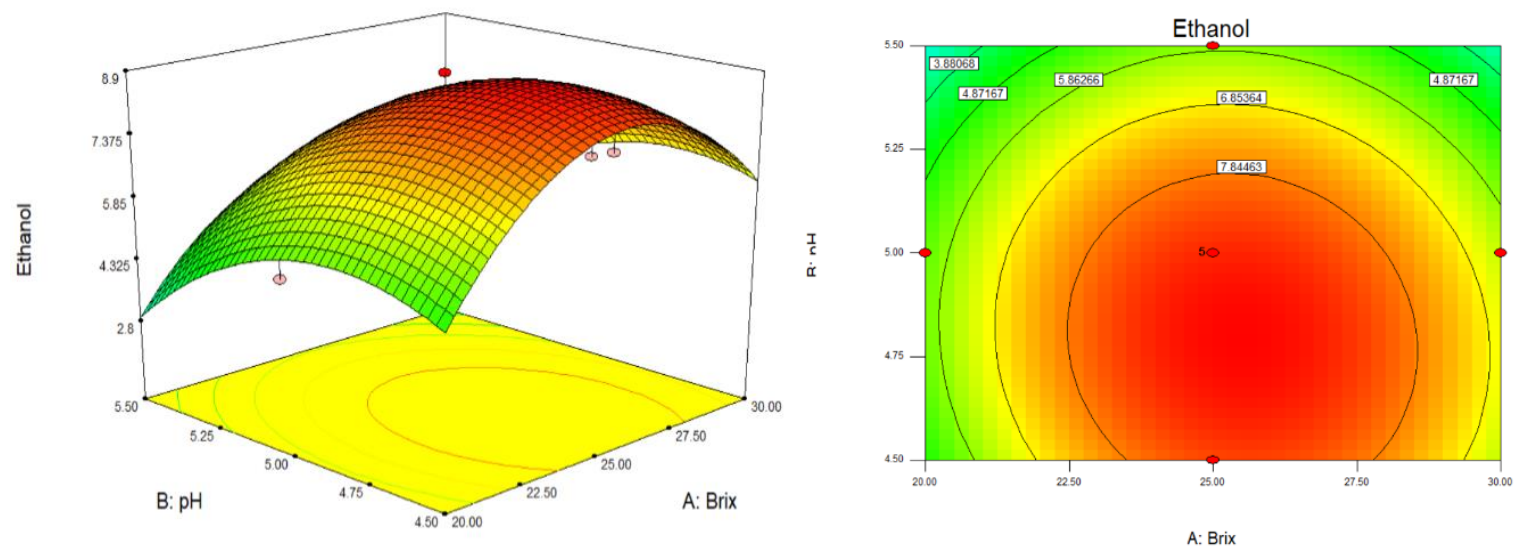

Hình 1. Biểu đồ bề mặt đáp ứng thể hiện sự tương quan giữa $\mathrm{pH},{ }^{\circ} \mathrm{Brix}$.

Tuy nhiên, việc lựa chọn điều kiện lên men phù hợp với dòng nấm men S. cerevisiae sao cho độ cồn thu hồi đạt giá trị cao nhất dựa vào mô hình tối ưu hóa theo phương trình (1) với các nghiệm thức tối ưu được đề xuất từ phần mềm thống kê. Bảng 4 thể hiện các thông số tối ưu từ mô hình thống kê với hàm lượng ethanol dự đoán cao nhất được lựa chọn để thực hiện thử nghiệm xác nhận.

\section{Bảng 4. So sánh độ cồn thực tế và độ cồn lý thuyết từ phần mềm Design Expert 7.0}

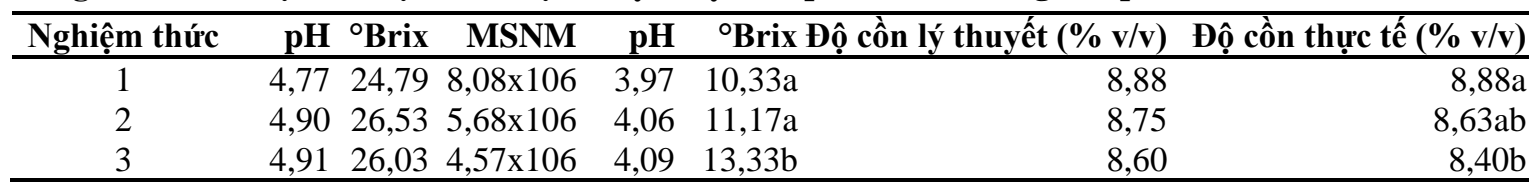

Số liệu là trung bình của 3 lần lặp lại. Trong cùng một cột, các số có mang số mũ giống nhau thì khác biệt không ý nghĩa thống kê ở múc $5 \%(P<0,05)$.

Bảng 4 cho thấy độ cồn thực tế thu được tương đương với độ cồn theo thuật toán đưa ra từ phần mềm Design Expert 7.0. Điều này chứng tỏ sự tính toán mô hình và thực nghiệm tương đối thống nhất với độ tin cậy là $95 \%$. Độ cồn thực tế của nghiệm thức 1 đạt cao nhất là $8,88 \% \mathrm{v} / \mathrm{v}$ khác biệt không có ý nghĩa với nghiệm thức 2 có độ cồn là $8,63 \% \mathrm{v} / \mathrm{v}$ nhưng khác biệt có ý nghĩa thống kê so với nghiệm thức 3. Tuy nhiên, nghiệm thức 1 với $\mathrm{pH} 4,77$, $24,79^{\circ}$ Brix và $\mathrm{MSNM} 8,08 \times 10^{6}$ được lựa chọn là nghiệm thức tối ưu vì cho độ cồn thực tế cao nhất. Đồng thời, đây là nghiệm thức cho độ cồn thực tế gần với độ cồn lý thuyết nhất trong ba nghiệm thức.

Theo Jackisch (1985), khả năng cho hàm lượng rượu khác nhau từ quá trình lên men có thể thay đồi theo nguồn nguyên liệu lên men, dòng nấm men và môi trường lên men. Điều kiện tối ưu cho lên men rượu vang chùm ruột với $\mathrm{pH} 4,77$ và $24,79^{\circ}$ Brix cao hơn so với nghiên cứu của Huỳnh Ngọc Thanh Tâm và ctv. (2020) trên dịch trái trâm $(\mathrm{pH} 4,22$; 24,6 ${ }^{\circ}$ Brix và $\mathrm{MSNM} 5,7 \times 10^{6} \mathrm{tb} / \mathrm{mL}$ ).

\subsection{Hoạt tính kháng oxy hóa của dịch trái chùm ruột và rượu vang chùm ruột}

\subsubsection{Các hợp chất thực vật}

Các hợp chất thực vật được xác định bằng phương pháp quang phổ với các bước sóng khảo sát có độ hấp thụ cực đại tương ứng với từng hợp chất. Ở mồi bước sóng, giá trị hấp thụ càng cao thì sự hiện diện của hợp chất thực vật càng nhiều. Một số hợp chất thực vật có trong dịch trái chùm ruột và rượu vang chùm ruột được khảo sát và kết quả thử nghiệm định tính được thể hiện ở Bảng 5. 
Bảng 5. Đánh giá sự hiện diện của các hợp chất thực vật trong dịch trái chùm ruột và rượu vang chùm ruột

\begin{tabular}{cclcc}
\hline STT & Bước sóng $(\mathbf{n m})$ & Hợp chất tự nhiên & Dịch quả chùm ruột & Rượu vang chùm ruột \\
\hline 1 & 215 & Steroid & +++ & +++ \\
2 & 230 & Terpenoid & ++++ & ++++ \\
3 & 255 & Phenolic & ++++ & ++++ \\
4 & 260 & Quinone & ++++ & ++++ \\
5 & 265 & Tanin & ++++ & ++++ \\
6 & 300 & Flavonoid & +++ & +++ \\
7 & 450 & Carotenoid & + & ++ \\
8 & 543 & Anthocyanin & + & ++ \\
9 & 545 & Saponin & + & ++ \\
10 & 550 & Alkaloid & + & ++ \\
\hline
\end{tabular}

Chỉ tiêu đánh giá định tính một số hợp chát tụ nhiên: $O D<0,1:+, 0,1<O D<0,5:++, 0,5<O D<1:+++, O D>1:++++$.

Bảng 5 cho thấy sự hiện diện của 10 hợp chất thực vật tự nhiên trong dịch trái chùm ruột và rượu vang chùm ruột. Kết quả này phù hợp với Andrianto et al. (2017), tác giả đã định tính sơ bộ và chỉ ra sự hiện diện của flavonoid, alkaloid, phenolic, terpenoid, saponin và glycoside trên dịch trái chùm ruột. Hợp chất phenolic hiện diện nhiều nhất trong dịch trái chùm ruột, tuy nhiên sự hiện diện của hợp chất này chỉ đứng thứ hai trong rượu vang chùm ruột, xếp sau terpenoid.

\subsubsection{Hàm lương polyphenol tổng}

Kết quả cho thấy hàm lượng polyphenol tổng của 2 nghiệm thức dịch trái và rượu vang chùm ruột khác biệt có ý nghĩa thống kê. Trong đó, nghiệm thức rượu vang chùm ruột có hàm lượng polyphenol tổng cao hơn dịch trái với giá trị lần lượt là 297,573 $\mathrm{mg} \mathrm{GAE} / \mathrm{mL}$ và $174,549 \mathrm{mg} \mathrm{GAE} / \mathrm{mL}$. Điều này cho thấy hàm lượng polyphenol tổng củ dịch trái đã giảm sau 14 ngày lên men, vì trong quá trình lên men, nấm men đã sử dụng một lượng nhỏ các hợp chất này cho quá trình sinh trưởng và phát triển. Kết quả này cũng tương đối phù hợp với kết quả định tính phenolic, tannin, quinone và flavonoid ở thí nghiệm trên.

Flavonoid và các hợp chất có liên quan đến polyphenol, có nhiều trong các loại trái cây và rau củ, được sử dụng cho mục đích ăn kiêng, dược liệu và phòng ngừa một số bệnh. Các hợp chất polyphenol là một trong những hợp chất lớn và phổ biến nhất của nhóm chuyển hóa thứ cấp thực vật (Yadava \& Munin, 2011). Kết quả trên cho thấy hàm lượng polyphenol tổng có trong dịch trái và rượu vang chùm ruột cao hơn dịch trái trâm $(57,0 \mathrm{mg}$ $\mathrm{GAE} / \mathrm{mL})$ và nước lên men trái trâm $(55,0 \mathrm{mg}$ $\mathrm{GAE} / \mathrm{mL}$ ) trong nghiên cứu của Huỳnh Ngọc Thanh Tâm và ctv. (2020).

\subsubsection{Khả năng kháng sư oxy hóa}

Giá trị $\mathrm{IC}_{50}$ được sử dụng để so sánh khả năng ức chế $\mathrm{DPPH}$ của dịch quả và rượu vang chùm ruột là nồng độ của mẫu mà tại đó nó có thể ức chế $50 \%$ gốc tự do, tế bào hoặc enzyme. $\mathrm{IC}_{50}$ càng thấp thì khả năng ức chế gốc tự do của mẫu càng cao. Kết quả giá trị $\mathrm{IC}_{50}$ được thể hiện qua Bảng 6 .

Bảng 6. Giá trị IC50 của vitamin $\mathrm{C}$, dịch trái và rượu vang chùm ruột

\begin{tabular}{|c|c|c|}
\hline STT & Mẫu & $\begin{array}{r}\text { Giá trị } \mathrm{IC}_{50} \\
(\mu \mathrm{g} / \mathrm{mL})\end{array}$ \\
\hline 1 & Vitamin C (đối chứng) & $0,881^{\mathrm{c}}$ \\
\hline 2 & Dịch quả chùm ruột & $59,973^{\mathrm{a}}$ \\
\hline 3 & Rượu chùm ruột & $45,132^{\mathrm{b}}$ \\
\hline
\end{tabular}

Số liệu là trung bình của 3 làn lặp lại. Trong cùng một cột, các số có mang số mũ giống nhau thi khác biệt không ý nghĩa thống kê ở mức 5\% $(P<0,05)$

Bảng 6 cho thấy cả 2 nghiệm thức dịch trái và rượu vang chùm ruột đều có khả năng kháng oxy hóa với $\mathrm{DPPH}$. Giá trị $\mathrm{IC}_{50}$ của vitamin $\mathrm{C}$ thấp hơn dịch quả chùm ruột gấp khoảng 73 lần và rượu chùm ruột gấp khoảng 55 lần. Điều này cho thấy khả năng kháng oxy hóa của vitamin $\mathrm{C}$ cao hơn dịch trái và rượu vang chùm ruột, tuy nhiên sản phẩm rượu vang chùm ruột có khả năng kháng oxy hóa cao hơn gấp 1,3 lần so với dịch trái, khác biệt có ý nghĩa thống kê với độ tin cậy 95\%. Rượu vang chùm ruột có khả năng khử gốc tự do DPPH cao hơn dịch trái là do sau quá trình lên men đã chuyển đổi và sinh ra nhiều hợp chất đa dạng, các hợp chất này đã tác động đến khả năng khử gốc tự do của rượu vang chùm ruột.

Kết quả định tính đã cho thấy trong dịch ép cũng như rượu vang chùm ruột tồn tại các hợp chất thực vật như phenol và tannin, alkaloid, saponin, steroid, flavonoid và triterpenoid. Đây là các hợp chất thực 
vật điển hình đóng góp cho khả năng kháng oxy hóa của dịch ép và rượu vang chùm ruột.

\section{KẾT LUẬN}

Với các điều kiện lên men tối ưu là $\mathrm{pH} 4,77$, $24,79^{\circ}$ Brix và MSNM $8,08 \times 10^{6}$ tế bào $/ \mathrm{mL}$, dịch lên men trái chùm ruột sẽ đạt độ cồn cao nhất $8,88 \%$ v/v sau 14 ngày lên men. Có 11 hợp chất thực vật được xác định trong dịch trái chùm ruột và rượu vang chùm ruột bao gồm steroid, triterpenoid, phenol, tannin, flavonoid, quinone, saponin, antocyanin, glucose, carotenoid và alkaloid. Hàm lượng polyphenol tổng không thay đổi nhiều trong quá trình lên men, đạt giá trị 174,549 mg GAE/L của dịch trái chùm ruột và $297,573 \mathrm{mg}$ GAE/L của rượu vang chùm ruột. Trong thí nghiệm, khả năng khử gốc tự do $\mathrm{DPPH}$ có giá trị $\mathrm{IC}_{50}$ của dịch trái và rượu vang trái chùm ruột lần lượt là $59,973 \mu \mathrm{L} / \mathrm{mL}$ và $45,132 \mu \mathrm{L} / \mathrm{mL}$, chứng tỏ rượu vang chùm ruột có khả năng kháng oxy hóa tốt hơn dịch trái.

\section{TÀI LIỆU THAM KHẢO}

Andrianto, D., Widianti, W., \& Bintang, M. (2017). Antioxidant and cytotoxic activity of Phyllanthus acidus fruit extracts. IOP Conf. Series: Earth and Environmental Science 58. http://iopscience.iop.org/1755-1315/58/1/012022

Guan, X. \& Yao, H. (2008). Optimization of viscozyme $\mathrm{L}$ assisted extraction of oat bran protein using response surface methodology. Food Chemistry, 106(1), 345-351. https://doi.org/10.1016/j.foodchem.2007.05.041

Harbone, J. B. (1973). Phytochemical methods. Chapman \& Hall

Hossain, S. J., Basar, M. H., Rokeya, B., Arif, K. M. T., Sultana, M. S., \& Rahman M. H. (2013). Evaluation of antioxidant, antidiabetic and antibacterial activities of the fruit of Sonneratia apetala (Buch.-Ham.). Oriental Pharmacy and Experimental Medicine, 13, 95-102. https://doi.org/10.1007/s13596-012-0064-4
Huỳnh Ngọc Thanh Tâm, Đào Thanh Tâm, Nguyễn Thị Minh Trâm, Văn Thị Hồng Huê, Dương Thị Mai Thảo \& Nguyễn Đức Độ. (2020). Xác định điều kiện lên men và hoạt tính kháng oxy hóa của nước lên men trái trâm (Syzygium cumini L.). Tạp chi Khoa hoc Truờng Đại học Cần Tho, 5(2), 72-79. https://doi.org/10.46826/huafjasat.v5n2y2021.427

Jackisch, P. (1985). Modern Winemaking. Cornell University Press. https://doi.org/10.7591/9781501721816

Mohamed, Y.M. \& Amr, A.R. (2013). Hepatoprotective effect of avocado fruits against carbon tetrachloride-induced liver damage in male rats. World Applied Sciences Journal, 21(10), 1445-1452.

Monica, H. C., Bente, L. H., Kari, H. (2010). Therapeutic potential of Phyllanthus emblica (amla): the ayurvedic wonder. Nutrition journal, 21(1), 93-105.

Morton, J., Morton, J. F., \& Miami, F. L. (1987). Otaheite Gooseberry. In Fruits of Warm Climates, 217-219.

Nguyễn Đình Thưởng \& Nguyễn Thanh Hằng. (2007). Công nghệ sản xuất và kiểm tra cồn ethylic. Nhà xuất bản Khoa học và Kỹ thuật. Hà Nội.

Radecka, D., Mukherjee, V., Mateo, R. Q., Stojiljkovic, M., Foulquié-Moreno, M. R., \& Thevelein, J. M. (2015). Looking beyond Saccharomyces: the potential ofnon-conventional yeast species for desirable traits in bioethanol fermentation. FEMS Yeast Research., 15(6), fov053. http://doi.org/10.1093/femsyr/fov053

Tan, P. S., Tan, Y. E. N., L, Y. Q., \& Nafiah, A. M. (2020). Phyllanthus acidus (L.) Skeels: A review of its traditional uses, phytochemistry, and pharmacological properties. Journal of Ethnopharmacology, 253, 112610. https://doi.org/10.1016/j.jep.2020.112610

Yadava, R. N. S., \& Munin, A. (2011). Phytochemical analysis of some medicinal plants. Journal of Phytology, 3(12), 10-14. 